\title{
MEMBENTUK KARAKTER ANAK USIA DINI DENGAN MENGENALKAN CERITA RAKYAT
}

\author{
Ria Kurniawaty ${ }^{\text {a, } 1}$ \\ ${ }^{a}$ UIN Sulthan Thaha Saifuddin Jambi, Indonesia \\ ${ }^{1}$ riakurniawaty99@gmail.com
}

\begin{tabular}{l}
\hline Informasi artikel \\
\hline Received : \\
Januari 29, 2020. \\
Revised : \\
Agustus 17, 2020 \\
Publish : \\
Maret 09, 2020. \\
Kata kunci: \\
Karakter; \\
Anak Usia Dini; \\
Cerita Rakyat;
\end{tabular}

Keywords:

Character;

Early Childhood;

The Story of The

People;

\begin{abstract}
ABSTRAK
Kemerosotan moral bangsa seperti yang terlihat dalam kehidupan masyarakat sekarang ini, salah satunya disebabkan karena hilangnya nilai-nilai karakter dalam diri manusia. Pendidikan karakter bukan saja tugas sekolah, tetapi juga menjadi tugas keluarga dan masyarakat. Waktu terbaik untuk membentuk karakter dimulai sejak anak-anak, karena setelah remaja akan sulit untuk membentuk atau mengubah perilaku buruknya, dari kecil anak harus dididik dan dibiasakan dengan karakter yang baik, agar ketika dewasa karakter yang baik itu sudah tertanah dalam diri mereka. Salah satu cara yang dapat dilakukan adalah dengan membiasakan anak untuk mendengar atau membaca cerita rakyat yang ada didaerahnya masing-masing. Melalui cerita, guru dan orang tua bisa menceritakan tokoh-tokoh yang ada dalam cerita, mana tokoh yang baik dan mana tokoh yang jahat, mana yang boleh ditiru dan mana yang tidak boleh ditiru. Sehingga nantinya diharapkan anak tumbuh menjadi pribadi dengan akhlak terpuji. Ada banyak pesan moral dan nilai-nilai luhur bangsa yang terkandung dalam cerita rakyat, khususnya cerita rakyat dari Aceh, dengan membaca cerita rakyat anak juga akan lebih mengenal dan mencintai budaya bangsanya sendiri.

ABSTRACT
The decline of morality as seen in the lives of the community it is today,
one of them due to the loss of values in human character. Character
education is not only a school, but also the task of the family and the
community. The best time to establish character from children, because
after the teens will be difficult to establish or change the bad behavior,
from small children should be educated and conditioned with good
character, so when the adult characters who either already tertanah in
themselves. one of the ways that can be done is to introduce and
familiarize children to hear or read stories of people who are
didaerahnya each. through storytelling, the parent or teacher can tell
the existing figures in the story, where the character is good and where
the characters are evil, which can be replicated and which ones should
not be emulated. So that later the hoped the child grow up to be personal
with attitudes, commendable. There are many moral and lofty values
embodied in the nation's folklore, in particularfolk stories from Aceh, by
reading the folklore of children will also be more knowing and loving
culture of his own people.
\end{abstract}
the full texts of its articles and allow readers to use them for any other lawful purpose. 


\section{PENDAHULUAN}

Pengaruh arus globalisasi memberikan dampak positif dan negatif dalam bidang pendidikan dan budaya, dampak positif yaitu terciptanya kompetisi yang tajam diberbagai aspek kehidupan, sehingga melahirkan generasi-generasi yang tekun, disiplin, ulet dan pekerja keras. Sedangkan dampak negatif, salah satunya yaitu terjadinya kemerosotan moral masyarakat, kenakalan dan tindakan menyimpang yang dilakukan oleh remaja dan pelajar, seperti perkelahian antar pelajar, tawuran, pergaulan bebas, seks bebas, melanggar aturan sekolah, kurangnya etika dan sopan santun para pelajar, kurangnya rasa hormat kepada guru dan orang tua, pelajar yang tidak jujur, penyalahgunaan narkoba, lunturnya sikap saling menghormati sesama manusia dan hilangnya kasih sayang diantara manusia.

Kemorosotan moral generasi bangsa, sebagaimana yang terjadi sekarang ini, diyakini karena hilangnya nilai-nilai karakter dalam diri masyarakat, remaja, pelajar atau generasi bangsa. Dalam Undang-Undang (UU) Republik Indonesia Nomor 20 tahun 2003, tentang Sistem Pendidikan Nasional dinyatakan bahwa pendidikan nasional mempunyai tujuan untuk mengembangkan kemampuan bangsa dan membentuk watak serta peradaban bangsa yang bermartabat dalam rangka mencerdaskan kehidupan bangsa Indonesia, pendidikan nasional bertujuan untuk berkembangnya potensi anak didik agar anak didik tersebut dapat menjadi manusia yang bertaqwa serta beriman kepada Tuhan Yang Maha Esa, berilmu, sehat, berakhlak mulia, cakap, mandiri, kreatif, bertanggungjawab serta menjadi warga Negara Indonesia yang demokratif. Dari Undang-Undang (UU) tersebut dapat kita simpulkan bahwa pendidikan nasional bertujuan untuk mencerdaskan kehidupan bangsa, serta membentuk watak dan karakter bangsa. 
Pendidikan tidak cukup hanya membuat orang pandai tetapi juga harus mampu menciptakan karakter yang baik dan nilai-nilai luhur dalam dirinya, karena untuk menggapai kesuksesan tidak cukup hanya bermodalkan kepandaian intelektual saja, kepintaran yang dimiliki oleh seseorang hanya berkonstribusi 20 (dua puluh) persen dari keberhasilan seseorang, selebihnya 80 (delapan puluh) persen amat ditentukan oleh sederet potensi-potensi yang berkaitan dengan karakter (Direktorat Jenderal Pendidikan Dasar, 2011). Pendidikan karakter dapat mempengaruhi keberhasilan akademik. Contohnya, kalau anak disiplin maka akan dapat mempengaruhi kerajinannya dalam belajar sehingga kemampuan akademiknya lebih meningkat, jika seseorang punya daya juang yang kuat, maka dalam belajar, orang tersebut akan lebih tekun, ia tidak akan cepat mundur bila gagal, tetapi akan mencari jalan dan terus berjuang sampai memperoleh keberhasilan (Suparno, 2008).

Presiden Susilo Bambang Yudhoyono dalam pidatonya pada hari HardiknasHarkitnas tahun 2011, Presiden SBY, mengutip dari Aristoteles mengatakan ada dua keunggulan manusia (human excellent): yaitu mempunyai keunggulan dalam karakter dan keunggulan dalam pemikiran, keunggulan karakter dan pemikiran manusia itu dapat dibentuk, dibangun serta dikembangkan melalui pendidikan, sasaran pendidikan bukan hanya kecerdasan ilmu pengetahuan, tetapi juga budi pekerti, moral, perilaku, watak, nilai, mental dan kepribadian yang mulia, dan tangguh (Direktorat Jenderal Pendidikan Dasar, 2011)

Waktu terbaik untuk membentuk karakter dimulai sejak anak-anak, seperti yang disampaikan oleh Sa'ad Karim, Pendidikan yang baik adalah pendidikan yang dilakukan sejak dini (Karim, 2006). Dalam Undang-Undang nomor 23 tahun 2002, dikatakan bahwa anak adalah seseorang yang belum berusia 18 tahun termasuk anak 
yang masih ada dalam kandungan ibunya. Adapun waktu yang dapat digunakan atau jangka waktu untuk membentuk karakter seorang anak sangat terbatas, kita hanya bisa melakukannya saat mereka balita sampai mencapai usia remaja, setelah masa remaja maka akan sangat sulit untuk merubah kelakuan (perilaku) buruknya (Edy, 2012).

Pola asuh di rumah dan pola didik di sekolah pada saat ini, akan menentukan atau mempengaruhi perilaku bangsa Indonesia di masa depan. Dengan pola asuh yang baik, anak akan menjadi pribadi dengan karakter baik sebaliknya pola asuh yang tidak baik, akan membentuk karakter buruk anak ketika dewasa. Sejak kecil anak harus dididik dan dibiasakan dengan karakter yang baik, agar ketika dewasa perilaku yang baik itu sudah ada dalam diri mereka. Pendidikan karakter bukan saja tugas sekolah, tetapi juga menjadi tugas keluarga dan masyarakat. Mengingat betapa pentingnya pendidikan karakter dimulai sejak dini pada anak, salah satu cara yang dapat dilakukan adalah dengan membiasakan anak untuk mendengar ataupun membaca cerita rakyat yang ada didaerahnya masing-masing (Edy, 2012).

Melalui bercerita, guru ataupun orang tua dapat menceritakan karakter tokohtokoh yang ada dalam cerita dan memberikan gambaran tentang karakter tokoh yang bisa ditiru dan karakter tokoh yang tidak boleh ditiru. Sehingga, dengan begitu si anak akan mengetahui perilaku dari tokoh yang bersangkutan (Masbukin, 2010). Melalui bercerita, orangtua atau guru bisa menanamkan nilai-nilai moral, dan nilainilai karakter, sehingga anak nantinya diharapkan tumbuh dan berkembang dengan kepribadian dan akhlak yang terpuji. Cerita rakyat dapat membantu dalam proses pembentukan karakter anak, karena disana banyak terkandung pesan moral dan nilai- 
nilai luhur bangsa. Dengan membaca cerita rakyat, maka anak akan lebih mengenal dan mencintai budaya bangsanya sendiri.

\section{METODE}

Penelitian ini merupakan studi teks dengan jenis kualitatif dengan objek penelitian yaitu membentuk karakter anak. Subjek dalam penelitian ini beberapa cerita rakyat yang dapat membentuk karakter anak usia dini. Pengumpulan data dilakukan dengan teknik mengumpulkan beberapa cerita rakyat. Analisis data yang digunakan mengacu kepada Miles dan Huberman yakni adanya reduksi data, sajian data dan merumuskan kesimpulan.

\section{PEMBAHASAN}

Karakter berasal dari kata charassein, menurut beberapa literatur pengertiannya sama dengan akhlak yaitu kebiasaan, perangai dan tabiat. Istilah karakter diambil dari bahasa Yunani "Charassian" yang berarti to mark. Dari istilah tersebut dapat diartikan pertama karakter adalah gambaran dari tingkah laku seseorang, jika seseorang berprilaku tidak baik, suka berbohong, kejam, maka orang tersebut mempunyai karakter yang jelek, sebaliknya jika seseorang mempunyai perilaku yang baik, jujur, serta suka menolong, maka orang tersebut mempunyai karakter mulia. Karakter adalah perilaku yang dilandasi oleh nilai-nilai berdasarkan norma agama, kebudayaan, hukum/konstitusi, adat istiadat dan estetika (Widayanti, 2012; Ainusyamsi, 2010).

Megawangi mendefinisikan pendidikan karakter adalah sebuah usaha untuk mendidik anak, sehingga nantinya anak dapat mengambil keputusan dengan bijak 
dan mempraktekkannya dalam kehidupan sehari-hari dan anak dapat memberi halhal yang positif kepada lingkungannya. Definisi lain yang dikemukakan oleh Gaffar, pendidikan karakter merupakan sebuah proses untuk menstransfer nilai-nilai kehidupan agar tumbuh dan berkembang dalam kepribadian seseorang sehingga nantinya dapat menjadi satu dalam perilaku kehidupan orang itu (Megawangi, 2004; Dharma, 2013).

Pendidikan karakter adalah usaha yang dilakukan secara sadar dan sengaja, yang bertujuan untuk membantu manusia agar dapat memahami, peduli serta melaksanakan nilai-nilai etika inti. Pendidikan karakter bertujuan untuk mengajarkan kebiasaan cara berperilaku dan berfikir yang dapat membantu setiap individu untuk hidup dan bekerja sama sebagai masyarakat, keluarga, dan bangsa serta bertujuan membantu orang lain untuk membuat keputusan yang dapat dipertanggung jawabkan (Zubaidi, 2011; Asmani, 2011).

Pendidikan karakter adalah pendidikan yang bertujuan untuk mendidik budi pekerti plus, yaitu melibatkan aspek pengetahuan, perasaan dan tindakan. Pendidikan karakter merupakan standar-standar batin yang diterapkan dan dilaksanakan dalam berbagai bentuk derajat atau mutu kualitas diri. Yang dilandasi nilai-nilai serta cara berfikir berdasarkan nilai-nilai tersebut dan terwujud dalam perilaku (Azzet, 2011; Rahardjo, 2010).

Dari beberapa definisi pendidikan karakter yang telah diuraikan diatas, maka dapat diambil kesimpulan bahwa pendidikan karakter adalah proses pendidikan yang mengajarkan cara berperilaku yang baik dan benar serta membantu individu untuk memahami nilai-nilai perilaku orang lain. 
Tujuan pendidikan karakter berdasarkan UUSPN No 20 tahun 2003 bab 2 pasal 3, fungsi dan tujuan pendidikan nasional yaitu mengembangkan kemampuan dan membentuk watak serta peradaban bangsa Indonesia yang bermartabat dalam rangka mencerdaskan kehidupan bangsa, dan bertujuan untuk berkembangnya potensi anak didik agar menjadi manusia yang bertakwa dan beriman kepada Tuhan yang Maha Esa, mempunyai akhlak mulia, berilmu, sehat, cakap, berjiwa mandiri, kreatif, serta menjadi warga negara yang demokratis dan bertanggung jawab (Rahardjo, 2010)

Pendidikan karakter bertujuan agar lebih meningkatkan mutu penyelenggaraan dan hasil pendidikan di sekolah yang terarah pada tercapainya pembentukan karakter dan akhlak mulia peserta didik secara utuh, terpadu dan seimbang, sesuai dengan standar kompetensi lulusan. Demikian pula seperti yang dikemukakan oleh Barmawi dan Arifin, pendidikan karakter disekolah mempunyai tujuan agar terjadinya perubahan anak didik pada 3 (tiga) aspek yaitu kognitif, afektif dan psikomotorik, sedangkan tujuan akhirnya adalah terwujudnya insan yang berilmu dan berkarakter (Muryati, 2013; Barmawi, 2012).

Sementara itu tujuan pendidikan karakter di sekolah menurut Kesuma yaitu (a) Menguatkan dan mengembangkan nilai-nilai kehidupan yang dianggap penting sehingga melekat pada pribadi peserta didik sebagaimana nilai-nilai yang dikembangkan, (2) Mengoreksi perilaku anak didik yang tidak cocok dengan nilainilai yang dikembangkan oleh sekolah, (3) membangun hubungan yang baik dengan keluarga dan masyarakat dalam memerankan tanggungjawab pendidikan karakter secara bersama-sama.

Pendidikan karakter bukan hanya untuk memberitahukan mana yang benar dan mana yang salah, lebih dari itu, pendidikan karakter mengajarkan hal yang baik, 
sehingga peserta didik menjadi mengerti (paham) tentang mana yang baik dan tidak baik, mampu merasakan nilai yang baik dan biasa melakukannya. Maka pendidikan karakter bukan hanya melihat dari sudut pandang pengetahuan yang baik akan tetapi juga menekankan pada perilaku yang baik. Pendidikan karakter menekankan pada hibit atau kebiasaan yang selalu (terusmenerus) dilaksanakan (dipraktikkan) dan dilakukan. Berdasarkan paparan di atas dapat disimpulkan bahwa, pendidikan karakter bertujuan untuk membentuk pribadi yang bermoral, beretika, bertanggungjawab, dan peduli kepada sesama (Ramly, 2011).

Nilai-nilai karakter yang perlu diajarkan kepada anak adalah nilai-nilai umum (universal) yang mana seluruh agama, budaya serta tradisi pasti menjunjung tinggi nilai-nilai tersebut. Nilai-nilai umum (universal) itu harus melekat pada seluruh anggota masyarakat walupun berbeda latar belakang budayanya. Karakter ada yang bersifat universal dan abadi seperti nilai kedisiplinan dan kejujuran, tetapi ada juga karakter yang mengikuti perkembangan zaman. Zaman telah berubah, teknologi juga berkembang dan era global juga terbuka, siswa/anak juga belajar dari perubahanperubahan itu. Lebih lanjut dalam konteks pendidikan karakter, seyokgyanya siswa/anak diarahkan agar memiliki karakter abadi dan universal seperti, kedisiplinan, menghargai, kejujuran, mempunyai empati, rasa kasih sayang, simpati dan pluralisme. Semua aspek ini akan menunjang kesuksesan siswa/anak dimasa mendatang (Ramly, 2011).

Orang yang berkarakter adalah orang yang menerapkan dan menjalankan perilaku yang baik dalam tindakanya sehari-hari dan bersumber dari hati yang baik. Terdapat 9 (Sembilan) nilai dasar karakter yang berasal dari nilai-nilai luhur universal yaitu : (1) karakter cinta kepada tuhan dan kepada ciptaan-Nya, (2) 
kejujuran/amanah, diplomatis, (3) mandiri dan bertanggungjawab, (4) hormat dan santun (baik budi bahasa dan tingkah laku), (5) percaya diri dan pekerja keras, (6) dermawan (murah hati), suka menolong dan gotong royong/kerjasama, (7) kepemimpinan dan keadilan, (8) baik dan rendah hati (tidak sombong), (9) karakter toleransi, kedamaian dan kesatuan (Muryati, 2013).

Ginanjar menambahkan ada 7 (tujuh) nilai yang merupakan hasil refleksi terhadap perjalanan bangsa Indonesia dari waktu ke waktu yang meliputi jujur, bertanggungjawab, visioner (memiliki wawasan kedepan), disiplin, kerja sama, adil (tidak memihak) dan peduli. Nilai-nilai karakter yang teridentifikasi dalam kehidupan saat ini meliputi sabar, ulet, ceria, jujur, kerja keras, tegas, teguh, terbuka, visioner, mandiri, tegar, pemberani, reflektif, tanggung jawab dan disiplin (Kesuma, 2013).

Sementara itu IHF (Indonesia Heritage Foundation) telah menyusun nilainilai yang layak diajarkan kepada anak-anak, yang dirangkum dalam 9 (Sembilan) pilar karakter, yaitu31 : (1) cinta kepada Tuhan dan kepada semua ciptaan-Nya, (2) hormat dan santun (3) jujur, amanah dan bijaksana, (4) mandiri dan bertanggungjawab, (5) murah hati, suka menolong dan gotong royong, (6) percaya diri, kreatif/ memiliki daya cipta dan pekerja keras (7) kepemimpinan dan keadilan/ tidak memihak, (8) baik dan rendah hati, (9) bersikap toleran, kedamaian dan kesatuan (Megawangi, 2004).

Adapun faktor yang sangat berpengaruh terhadap pembentukan karakter anak, yaitu: Keluarga, merupakan tempat pertama dimana anak dididik dan dibesarkan, pola asuh orang tua sangat berpengaruh dalam membentuk karakter anak. orang tua adalah orang yang mempunyai peran pertama dalam mendidik karakter anak, nilai 
karakter mana yang mau ditekankan disekolah, perlu dikomunikasikan dengan orang tua sehingga ada kerjasama, antara guru dan orang tua, misalnya disekolah ditekankan agar anak menghargai orang lain tanpa membedakan warna kulit, golongan, suku, ekonomi, agama dan sebagainya, maka orang tua juga diajak untuk menanamkan nilai ini kepada anak. Keluarga merupakan pondasi awal pendidikan karakter anak. Nurla Isna Aunillah mengungkapkan bahwa orang tua harus mengusahakan agar rumah benar-benar terasa sebagai sekolah bagi anaknya. Sehingga tercipta suasana yang mendukung bagi anak untuk mendapatkan pengetahuan yang berguna bagi dirinya (Suparno, 2008; Aunillah, 2011).

Sekolah merupakan salah satu tempat yang tepat untuk menerapkan pendidikan karakter, setiap anak akan menempuh pendidikan atau belajar disekolah, apa yang didapatkan dan dipelajari disekolah juga akan mempengaruhi karakter anak.

Masyarakat juga menjadi pendidik yang penting, bila di sekolah menekankan pendidikan karakter, sedangkan masyarakat tidak mendukung ataupun menyokongnya, maka pendidikan menjadi berat atau bahkan akan gagal, misalnya sekolah mengajarkan nilai persaudaraan, sedangkan dimasyarakat selalu dilihat konflik antar suku, anak akan sulit mengembangkan persatuan, disini banyak soal terjadi, anak disekolah dibantu baik, tetapi karena lingkungan dimasyarakat masih kurang baik, maka anak akan meniru lingkungan masyarakat yang kurang baik (Suparno, 2008).

Pendidikan Anak Usia Dini merupakan jenjang atau tahapan pendidikan awal bagi anak. Pada usia dua tahun, sekitar 80 persen otak anak sudah berkembang. Penelitian menunjukkan bahwa anak yang lahir dengan 100 milyar sel otak. Ketika memasuki usia dini, koneksi sel otak anak tersebut berkembang sampai beberapa kali 
lipat dari koneksi awal yaitu sekitar 20.000 koneksi. Hal ini menyebabkan anak mampu menyerap semua hal positif atau negatif yang ada dilingkungannya. Jika anak terbiasa berada di lingkungan positif maka akan terbentuk perilaku anak yang positif, demikian pula sebaliknya. Dalam Peraturan Menteri Pendidikan dan Kebudayaan Republik Indonesia, nomor 137 tahun 2014, pendidikan anak usia dini merupakan suatu proses pembinaan yang diberikan kepada anak semenjak anak lahir sampai dengan usia enam tahun, yang dilakukan dengan memberikan pendidikan awal yang berguna untuk membentuk pertumbuhan dan perkembangan jasmani dan rohani sehingga anak mempunyai persiapan dalam memasuki pendidikan selanjutnya (Jalongo, 2007).

Cerita rakyat memiliki empat fungsi yaitu: (1) sebagai sistem proyeksi atau alat yang mencerminkan angan-angan kolektif, (2) sebagai alat pengesahan pranatapranata dan lembaga kebudayaan, (3) sebagai alat pendidikan anak, (4) sebagai alat untuk mengawasi norma-norma masyarakat.

Bercerita memiliki beberapa manfaat. Antara lain (1) kisah atau cerita memiliki pengaruh yang sangat besar dalam menarik perhatian pendengar, (2) kisah atau cerita mengandung ibrah dan nasihat, (3) kisah memiliki posisi yang sangat berguna dalam membentuk kepribadian anak, dan (4) kisah merupakan sarana pendidikan yang efektif (Aziz, 2008).

Pada sebuah cerita terdapat amanat yang sangat penting bagi perkembangan pola pikir anak-anak, tokoh dalam cerita dapat menjadi contoh atau teladan bagi anak. Melalui cerita yang didengar atau dibaca, tanpa disadarinya, anak telah menyerap beberapa sifat positif, seperti kejujuran, keberanian, kerja keras, saling mencintai 
sesama manusia, menyayangi binatang, mandiri, serta anak belajar untuk membedakan hal-hal yang baik dan buruk.

Karakteristik cerita anak yang sudah disesuaikan untuk anak Indonesia oleh Musfiroh, dijelaskan dalam tujuh karakteristik, yaitu tema, amanat, tokok, plot, sudut pandang, latar dan sarana kebahasaan, untuk anak sebaiknya dipilih tema ketuhanan, sosial, kebenaran dan kejahatan dan mengandung pesan moral untuk anak. Dalam hal ini guru ataupun orang tua harus memilih cerita yang mengandung pesan moral untuk anak (Musfiro, 2005).

Cerita rakyat dibagi dalam 3 (tiga) golongan besar, yaitu sebagai berikut: (a) Mitos/mite, yaitu cerita rakyat yang menurut si empunya cerita pernah benarbenar terjadi serta dianggap suci, ditokohi oleh para dewa atau makhluk setengan dewa. (b) Lagenda/lagend, yaitu cerita rakyat yang menurut pendapat si empunya cerita dianggap benar-benar ada, tetapi tidak dianggap suci, berbeda dengan mite, tokoh dalam lagenda lebih bersifat duniawi. (c) Dongeng/falkto yaitu cerita rakyat yang tidak benar-benar terjadi, tidak terkait waktu ataupun tempat, umumnya dongeng tidak diketahui pengarangnya (anonim).

Sebuah cerita mempunyai manfaat sebagai berikut: (a) Membantuuntuk membentuk pribadi dan moral anak Anak yang sudah terbiasa menyimak dan membaca cerita, dalam jiwa mereka akan tumbuh menjadi pribadi yang baik serta memiliki kecerdasan interpersonal yang tinggi. Selain itu cerita juga dapat membantu dalam pembentukan dan perkembangan moral mereka. (b) Menyalurkan Kebutuhan Imajinasi Anak membutuhkan tempat untuk menyalurkan imajinasi, tentang berbagai hal yang selalu muncul dalam pikiran mereka. Pada saat mendengar cerita, imajinasi anak mulai dirangsang. Anak membayangkan apa yang terjadi dalam 
cerita dan tokoh yang terlibat dalam cerita tersebut. Imajinasi atau daya pikir yang dibangun anak saat menyimak cerita memberikan pengaruh yang positif terhadap kemampuan anak dalam menyelesaikan masalah, (c) Memacu Kemampuan Verbal Cerita dapat mendorong anak untuk suka berbicara dan senang bercerita. Sehingga akan terlatik anak dalam berdialog, berdiskusi antar teman. (d) Membuka Cakrawala Pengetahuan Dengan membaca cerita atau mendengar cerita, anak akan lebih mengetahui karakteristik budaya bangsa, seperti mengenal nama-nama tempat cerita, gaya bahasa-bahasa yang digunakan dalam cerita atau ungkapanungkapan yang dipakai dalam cerita tersebut. Hal itu tentu akan menambah pengetahuan anak tentang hal yang belum diketahuinya (Musfiro 2005).

Cerita rakyat merupakan salah satu sarana pembelajaran bagi anak, anak dapat mengenal sejarah dan kekayaan bangsa Indonesia. Indonesia kaya akan cerita rakyat, contohnya di Aceh, ada banyak cerita rakyat, yang sekarang ini sudah mulai hilang di tengah-tengah masyarakat/anak-anak Aceh. Hal ini disebabkan karena jarangnya orang tua dan guru, menceritakannya. Padahal banyak pesan moral dibalik cerita rakyat dari Aceh

Ada banyak Pesan moral dan nilai-nilai luhur bangsa yang terkandung dalam cerita rakyat dari Aceh yg dapat diambil untuk disampaikan kepada anak, pesan moral tersebut, dapat digunakan untuk mendidik karakter anak sekaligus dapat membantu perkembangan moral anak, seperti yang terlihat dalam tabel berikut ini: 


\begin{tabular}{|c|c|c|}
\hline Judul Cerita & $\begin{array}{l}\text { Pesan moral yang } \\
\text { terkandung dalam cerita }\end{array}$ & $\begin{array}{c}\text { Nilai-nilai pendidikan } \\
\text { karakter }\end{array}$ \\
\hline $\begin{array}{l}\text { Putri pukes dan danau } \\
\text { laut tawar }^{41}\end{array}$ & $\begin{array}{l}\text { Patuhilan pesan orang tua, } \\
\text { karena itu semua demi } \\
\text { kebaikan kita }\end{array}$ & $\begin{array}{l}\text { - Hormat/santun } \\
\text { - Menghargai orang tua }\end{array}$ \\
\hline Mentiko bertuah $^{42}$ & $\begin{array}{l}\text { Belajarlah dengan baik, agar } \\
\text { kita menjadi orang yang } \\
\text { berguna }\end{array}$ & $\begin{array}{l}\text { - Kerja keras } \\
\text { - Disiplin }\end{array}$ \\
\hline Mentiko betuah $^{43}$ & $\begin{array}{l}\text { Manusia adalah makhluk } \\
\text { sosial, maka perlu sikap } \\
\text { tolong menolong Akibat } \\
\text { buruk jika terlalu } \\
\text { memanjakan anak dan setiap } \\
\text { perbuatan pasti ada } \\
\text { balasannya. Akibat buruk jika } \\
\text { berbuat licik }\end{array}$ & $\begin{array}{l}\text { - Dermawan, suka tolong } \\
\text { Menolong } \\
\text { - Selalu berbuat baik }\end{array}$ \\
\hline $\begin{array}{c}\text { Gajah putih dan tari } \\
\text { guel }^{44}\end{array}$ & $\begin{array}{l}\text { Tarian yang dilakukan oleh } \\
\text { sangede bisa membuat gajah } \\
\text { menurutinya, jika kita ingin } \\
\text { membuat orang atau hewan } \\
\text { menuruti kita, maka } \\
\text { gunakanlah cara-cara yang } \\
\text { baik }\end{array}$ & $\begin{array}{l}\text { - Sabar } \\
\text { - Pemberani } \\
\text { - } \text { Baik dan rendah hati }\end{array}$ \\
\hline Raja parkit yang cerdik ${ }^{45}$ & $\begin{array}{l}\text { Kita harus sabar dan mencari } \\
\text { akal agar bisa keluar dari } \\
\text { kesulitan }\end{array}$ & $\begin{array}{l}\text { - Sabar } \\
\text { - Kerja keras } \\
\text { - Ulet } \\
\text { - Pemberani }\end{array}$ \\
\hline $\begin{array}{l}\text { Raja burung parkit yang } \\
\text { cerdik }^{46}\end{array}$ & $\begin{array}{l}\text { Jadilah orang yang baik dan } \\
\text { bijaksana, sebab orang yang } \\
\text { baik dan bijak akan di cintai } \\
\text { banyak orang }\end{array}$ & - Baik dan rendah hati \\
\hline Raja parkit $^{47}$ & $\begin{array}{l}\text { Kebebasan menjalani hidup } \\
\text { sesuai dengan keinginan hati, }\end{array}$ & - Baik dan rendah hati \\
\hline
\end{tabular}




\begin{tabular}{|c|c|c|}
\hline & $\begin{array}{l}\text { merupakan sesuatu yang } \\
\text { sangat berharga, harta benda } \\
\text { dan segala kemewahan tidak } \\
\text { menjamin seseorang untuk } \\
\text { hidup bahagia }\end{array}$ & \\
\hline Geugasi dan geugasa $^{48}$ & $\begin{array}{l}\text { Keberanian menegakkan } \\
\text { kebenaran dan ketulusan } \\
\text { membantu sesama adalah hal } \\
\text { terpuji, selama kita berada di } \\
\text { pihak yang benar, maka harus } \\
\text { terus di perjuangkan }\end{array}$ & $\begin{array}{l}\text { - } \\
\text { - } \text { Bemberanik dan rendah hati } \\
\text { - Dermawan dan suka } \\
\text { tolong menolong }\end{array}$ \\
\hline Batu belah ajaib ${ }^{49}$ & $\begin{array}{l}\text { - Kecorobohan seseorang } \\
\text { dapat } \\
\text { berdampak buruk pada diri } \\
\text { sendiri dan orang lain } \\
\text { - Dengarkanlah nasehat } \\
\text { kedua } \\
\text { orang tua, jika berbuat } \\
\text { salah } \\
\text { segeralah meminta maaf } \\
\text { kepada mereka }\end{array}$ & $\begin{array}{l}\text { - Sabar } \\
\text { - Menghargai orang tua } \\
\text { - Menghargai orang lain } \\
\text { - Hormat dan santun } \\
\text { - Saling memaafkan }\end{array}$ \\
\hline
\end{tabular}

\section{KESIMPULAN}

Cerita rakyat merupakan sarana hiburan dan pendidikan, dengan membaca atau mendengar cerita rakyat, anak dapat mempelajari karakter tokoh-tokoh dalam cerita. Melalui cerita, orangtua dan guru dapat menanamkan nilai-nilai moral, dan nilai-nilai karakter, sehingga anak nantinya akan tumbuh dan berkembang dengan kepribadian dan akhlak yang terpuji. Cerita rakyat dapat membantu dalam proses pembentukan karakter anak, karena disana banyak terkandung pesan moral dan nilai-nilai luhur bangsa. Dengan membaca cerita rakyat, maka anak akan lebih mengenal dan 
mencintai budaya bangsanya sendiri. Namun orang tua atau guru, harus memilih cerita rakyat yang cocok dan cerita yang disampaikan harus sesuai dengan usia anak. Waktu terbaik untuk membentuk karakter seorang anak yaitu saat mereka balita hingga mencapai usia remaja, setelah remaja akan sulit untuk membentuk serta mengubah perilaku buruknya.. 


\section{REFERENSI}

Aryasih, Putu Putri, dkk. Pengembangan Aplikasi Augmented Reality Story Book Panji Sakti, Kumpulan Artikel Mahasiswa Pendidikan Teknik Informatika (KARMAPATI), ISSN 2252-9063, Volume 3, Nomor 5, Oktober 2013.

Ainusyamsi, Fadlil Y, Pendidikan Karakter di Jepang, Makalah Seminar Internasional dan Workshop Pendidikan Karakter Menuju Terbentuknya Masyarakat yang Berbudi Pekerti Luhur, Bandung: UPI, 2010.

Asmani, J.M, Buku Panduan Internalisasi Pendidikan Karakter di Sekolah, Yokyakarta : Diva Press, 2011.

Ayu, D. Cerita Rakyat Nusantara 34 Provinsi, Jakarta: Wahyu Media, 2015.

Azzet, Akhmat Muhaimin. Urgensi: Pendidikan Karakter di Indonesia, Yokyakarta : Ar-Ruzz Media, 2011.

Asy-Syalhub, Fuad Abdl Aziz. Begini Seharusnya Menjadi Guru: Panduan Lengkap Metodologi Pengajaran Cara Rasulullah. Jakarta: Darul Haq, 2008.

Barmawi dan Arifin, M. Srategi dan Kebijakan: Pembelajaran Pendidikan Karakter, Yokyakarta: Ar-ruzz Media, 2012.

Direktorat Jenderal Pendidikan Dasar, Pendidikan Karakter untuk Membangun Karakter Bangsa, Majalah Policy Brief. Edisi 4 Juli 2011.

Danandjaja, James. Folklor Indonesia, Jakarta: Grafiti Press, 2007.

Edy, Ayah, Membangun Indonesia yang Kuat dari Keluarg,. Jakarta: Tangga Pustaka, 2012.

Jalongo, Mary R. Early Childhood Language Art. USA : Pearson Education, Inc, 2007

Kesuma. Dharma, dkk. Pendidikan Karakter: Kajian Teori dan Praktik di Sekolah. Bandung: Remaja Rosdakarya, 2013.

Megawangi, Ratna. Pendidikan Karakter, Jakarta: Indonesia Heritage Foundation, 2004.

Muryati, Sri. Pendekatan Inkuiri Moral sebagai Alternative Metode Pendidikan Karakter Siswa di SMP. Majalah Ilmiah Pawiyatan, Volume XX Nomor 4, Oktober 2013

Musbikin, I. Buku Pintar PAUD, Yogyakarta: Laksana, 2010.

Musfiroh, Tadkiroatun, Bercerita untuk Anak Usia Dini, Jakarta: Departemen Pendidikan Nasional, Dirjen Dikti, 2005

Nuralla, L dan Imadudin, L, Cerita Rakyat Nusantara Terpopuler, Bandung: Ruang Kota, 2009, cetakan ke-1. 
Nurla Isna Aunillah, Panduan Menerapkan Pendidikan Karakter di Sekolah, Yogyakarta: Laksana, 2011.

Rahardjo, Budi Sabar. Pendidikan Karakter sebagai Upaya Menciptakan Akhlak Mulia, Jurnal Pendidikan Kebudayaan. Volume 16 Nomor 3 Mei 2010 , Jakarta.

Ramly, Mansyur. Pedoman Pelaksanaan Pendidikan Karakter Berdasarkan Pengalaman di Satuan Pendidikan Rintisan, Jakarta: Kementerian Pendidikan dan Kebudayaan, pada Penelitian dan Pengembangan pusat kurikulum dan perbukuaan, 2011.

Reza, Marina. A, 108 Cerita Rakyat Terbaik Asli Nusantara, Jakarta: Visimedia, 2013.

Rouf, I dan Ananda, S. 100 Cerita Rakyat Indonesia dari Sabang Sampai Merauke. Jakarta: Anak Kita, 2013.

Sambangsari, S. Kumpulan Cerita Rakyat Nusantara, Jakarta: Wahyu Media, 2008.

Sa’ad Karim, Agar Anak tidak Durhaka, Jakarta: Pustaka Al-Kautsar, 2006.

Suparno, Paul, Pendidikan Karakter Solusi Kemerosotan Moral Bangsa, Majalah Opini, edisi 35, Oktober 2008.

Tamiwidiasari, Lagenda Rakyat Nusantara, Yokyakarta: Great Publisher (anggota Ikapi), 2010.

Widayanti, Ida S. Mendidik Karakter dengan Karakter, Jakarta: Argatilanta, 2012.

Zubaedi, Desain Pendidikan Karakter, Jakarta: Kencana, 2011. 